\title{
Characterization Micro/nanostructures of Barium Strontium Titanate
}

\author{
ABDELHALIM ELBASSET ${ }^{1,2}$, FARID ABDI', \\ TAJ-DINE LAMCHARFI ${ }^{1}$ and NOR-SAID ECHATOUI ${ }^{1}$ \\ 'LSSC Department of Electrical Engineering, Faculty of Science and Technology (FST), \\ Universit Sidi Mohamed Ben Abdellah y, Fes, Morocco. \\ 2Département de Physique, Université Sidi Mohammed Ben Abdellah, \\ Faculté des Sciences D-M, B.P.1796, Fès-Atlas Maroc. \\ *Corresponding author E-mail: elbasset.abdelhalim@gmail.com
}

http://dx.doi.org/10.13005/ojc/320326

(Received: April 06, 2016; Accepted: May 25, 2016)

\begin{abstract}
Structural characteristics of $\mathrm{Ba}_{0.0975} \mathrm{~S}_{0.025} \mathrm{TiO}_{3}\left(\mathrm{BS}_{0.025} \mathrm{~T}\right)$ ceramics calcined at different temperatures at 800,850 and $900^{\circ} \mathrm{C}$ for 4 hours hove been investigated. Results DRX showed that the change in the cell parameter along a axis (a) is more important than that along $c$ axis and is accompanied by spacing of these parameters. In addition they indicate that the diminuation of symmetry is caused by the increase of the calcination temperature This trend towards the tetragonale phase was confirmed by Raman spectroscopy. Electronic scan microscopy (SEM) has given the grains mean size, the latter increase and reaches a mean size of approximately $1.97 \mathrm{im}$ when the calcination temperature increases equals $900^{\circ} \mathrm{C}$.
\end{abstract}

Keywords: Structural characteristics, DRX, Raman spectroscopy.

\section{INTRODUCTION}

Barium titanate, $\mathrm{BaTiO}_{3}$ formula was discovered in the late 1940. It is the first single ferroelectric oxide known and today remains a model material for the study of ferroelectricity. Employed as a solid ceramic or thin layer, barium titanate is widely used in the industry for its dielectric and piezoelectric properties ${ }^{1}$. This material possesses nonlinear properties and may be developed for the realization of new frequency converters by frequency doubling by phase matching. This ternary compound with a perovskite structure is probably one for which literature is the most abundant and is qualified as one of the most prolific among the analyzed inorganic structures. Its properties, both optical and electrical, were proved to be technologically very promising, such as for example, the mirror conjugation pumper phase, the linear resonator, the phasing of laser sources and finally the active waveguides ${ }^{2}$. On the other hand the potential of $\mathrm{BaTiO}_{3}$ is linked particularly to the existence 
of piezoelectric properties ${ }^{3-5}$. The study of these properties is necessary before any development. The ultimate goal of this work is to study the effect of heat treatment temperature on the structural state of doped strontium barium titanate.

\section{Synthesis}

Solutions of barium acetate, Strontium carbonate and the ground $\mathrm{Ti}$ are mixed in stoichiometric proportions, depending on the chemical formulation $\mathrm{Ba}_{0.0975} \mathrm{~S}_{0.025} \mathrm{TiO}_{3}$ under agitation for $5 \mathrm{~min}$. The destabilization of this solution is assured by evaporation of the solvent in an oven at the temperature of $80^{\circ} \mathrm{C}$ for $96 \mathrm{~h}$. The different steps in the preparation of the $\mathrm{Ba}_{0.0975} \mathrm{~S}_{0.025} \mathrm{TiO}_{3}$ powders are similar to those we have in our previous work ${ }^{6}$. The xerogel obtained is ground in an agate mortar. Raw powder, after grinding, is calcined in air at different temperatures 800,850 and $900^{\circ} \mathrm{C}$ for $4 \mathrm{~h}$,

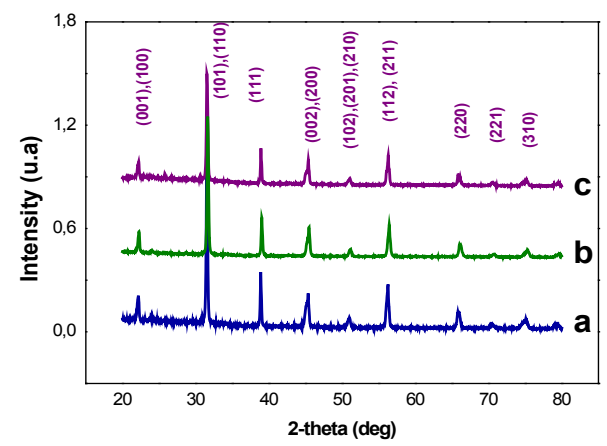

Fig. 1: XRD patterns of the $\mathrm{Ba}_{0.0975} \mathrm{~S}_{0.025} \mathrm{TiO}_{3}$ powder obtained at 800 (a), 850 (b), and $900^{\circ} \mathrm{C}$ (c)

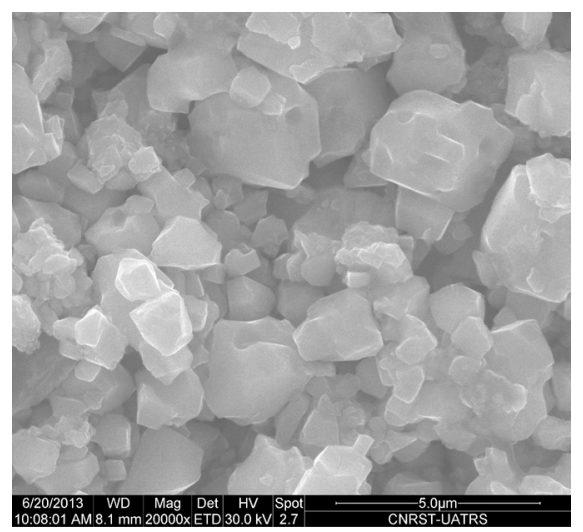

in a programmable oven. The effect of temperature on the structure of the obtained samples was studied by X-ray diffraction (RX), Raman spectroscopy and scanning electron microscopy (SEM).

\section{RESULTS}

Fig. 1 shows XRD spectra of $\mathrm{Ba}_{0.0975} \mathrm{Sr}_{0.025} \mathrm{TiO}_{3}$ powders calcined at different temperature for 4 hours. Thes specter reveal the crystallization of the powders in the perovskite phase with the presence of secondary microphase at $800^{\circ} \mathrm{C}$; this crystallization temperature is clearly lower than that of other processes, such as conventional solid and co-precipitation methode ${ }^{3-5}$ and even for the sol-gel preparation method ${ }^{10}$. On the other hand the secondary phase disappears at the calcination temperature $850^{\circ} \mathrm{C}$ for 4 hours. It is also observed that the crystallization peaks of the perovskite phase

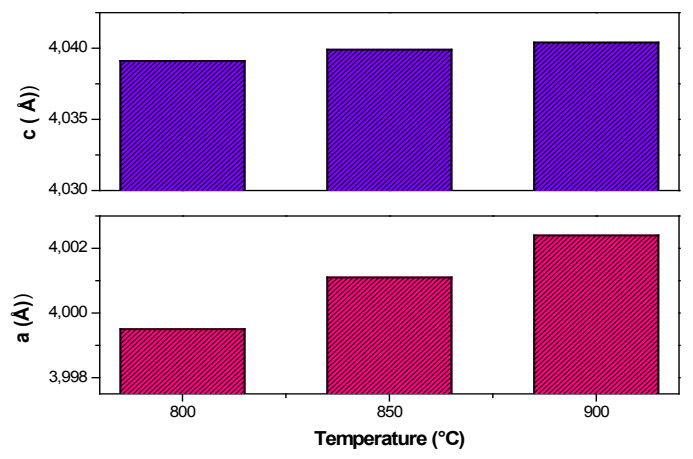

Fig. 2: Unit cell parameters (a) and (c) variation depending on temperature

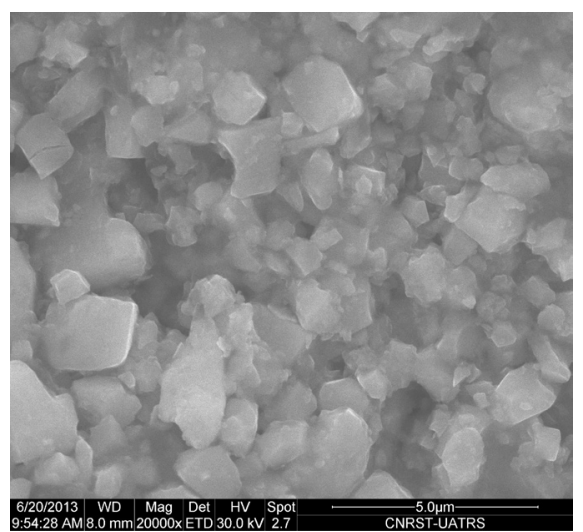

Fig. 3: SEM images of $\mathrm{Ba}_{0.0975} \mathrm{~S}_{0.025} \mathrm{TiO}_{3}$ nanoparticles synthesized at (a) 850 and (b) $900{ }^{\circ} \mathrm{C}$ for $4 \mathrm{~h}$ 


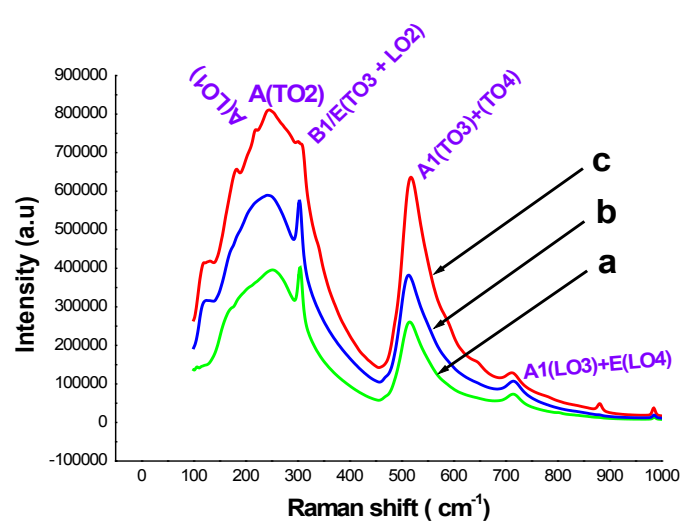

Fig. 4: Room temperature depolarized Raman spectra of the $\mathrm{Ba}_{0.0975} \mathrm{~S}_{0.025} \mathrm{TiO}_{3}$ calcined at 800 (a), 850 (b), and $900^{\circ} \mathrm{C}$ (c)

are becoming closer and more intense when the calcination temperature increases. This indicates a better crystallization of the phase. However, the increase of the calcination temperature causes the appearance of double peaks ((200) and (002)) in the vicinity of 41 in $2 \theta$, therefore, increased heat treatment may increase the quadracity of the ceramic ${ }^{11}$ and a sharp peak with narrow peak width is an indicator of Irge grain size ${ }^{12-13}$. On the other hand it is noted that the change in the lattice parameter along a axis is greater than that along $c$ axis and spacer supports the lattice parameters a and $c$ (Figure 2 ). We can learn from these analyzes that the observed decreasing symmetry is caused by the increase of the calcination temperature. Figure 3 shows the morphology and the grain size of the $\mathrm{BS}_{0.025} \mathrm{~T}$ ceramic sintered at $1100^{\circ} \mathrm{C}$ for 8 hours. The grains formed have a relatively uniform size and fairly regular. On the other hand it is important to note that the grains formed have a rather variable form with calcination temperature increase. Indeed for the calcination temperature $850^{\circ} \mathrm{C}$, the medium is of the order of $0.69 \mu \mathrm{m}$ which increases and reached an average size of about $1.97 \mu \mathrm{m}$ when the calcination temperature increases to $900^{\circ} \mathrm{C}$.

Raman spectra of the powder $\mathrm{Ba}_{0.0975} \mathrm{Sr}_{0.025} \mathrm{TiO}_{3}$ calcined at various temperatures are shown in Figure 4. Between 200 and $300 \mathrm{~cm}^{-1}$, there are two modes A (LO1) and A (TO2) boated around 218 and $247 \mathrm{~cm}^{-1}$ respectively, however the increase of the calcination temperature causes a gradual decrease in the intensity thereof to the appearance of a single broadband at $900^{\circ} \mathrm{C}$. We also observed a narrow band around $305 \mathrm{~cm}^{\prime \prime}$ associated with the modes $\mathrm{B} 1$ and $\mathrm{E}(\mathrm{TO} 3+\mathrm{LO} 2)$, and a wide and asymmetrical strip with $520 \mathrm{~cm}^{\text {"11 }}$ associated with the modes $\mathrm{A} 1$ (TO3) and $\mathrm{E}(\mathrm{TO} 4)$ and another wide peak (not very intense) around $720 \mathrm{~cm}^{\prime 1}$ associated with the modes $A 1(L O 3)$ and $E(L O 4)$. One may also note the increase in intensity of the mode $E(\mathrm{LO} 4) /$ $\mathrm{A} 1$ (LO3) by against that of $\mathrm{E}(\mathrm{TO} 3+\mathrm{LO} 2) / \mathrm{B} 1$ becomes very important. This is closely related to the significant increase in lattice parameters observed above in Figure 2. This indicates a trend towards the tetragonal phase. Indeed, many researchers agree on the fact that the presence of E (TO3) to $305 \mathrm{~cm}^{-1}$ mode around. Who comes from idle F2U of the cubic phase, is a characteristic of the tetragonal phase of the unit cel $\mathrm{BT}^{14-15}$. And that the decrease of the number of Raman bands is a consequence of an increase in the lattice symmetry ${ }^{13,16}$. Those are the consequence of shift of frequencies of the Raman modes. Besides, we have observed the presence of two bands at around 117 and $804 \mathrm{~cm}^{-1}$, which have not been reported in the literature; these bands are not detectable on the spectrum recorded at $900^{\circ} \mathrm{C}$, and their presence may be closely related to the secondary phase $\mathrm{BaCO}_{3}$, in accordance with $\mathrm{DRX}$ observation.

\section{CONCLUSION}

The structural analysis results found by $\mathrm{XRD}$ and Raman spectroscopy showed that the effect of heat treatment temperature is to change the structure from the pseudo cubic phase to the tetragonal phase by the large increase in the lattice parameter a. therefore heat treatment temperature decreases the symmetry of $\mathrm{Ba}_{0.0975} \mathrm{~S}_{0.025} \mathrm{TiO}_{3}$. Moreover, this study showed that the increase of the temperature of calcination lead a good crystallization of the $\mathrm{Ba}_{0.0975} \mathrm{~S}_{0.025} \mathrm{TiO}_{3}$ samples, but also to a large increase in the grain size.

\section{REFERENCES}

1. Hana, N.;Adel, M.; and Mohamed, M. Orient J Chem. 2013, 29(3), 937-944
2. Scott, J. F. Materials Science and Engineering B: Solid-State Materials for advanced 
Technology, 2005, I. 120, 6- 12.

3. Rawat, M. ; Yadav, K.L. Ceram. Int. 2013, 39, 3627-3633.

4. Wei-Gang, Y.; Bo-Ping, Z.; Nan, M.; Lei, Z. Journal of the European Ceramic Society . 2012, 32, 899-904

5. Kyung-Su, L.; Jung-Hyuk, K.; Ceramics International. 2013, 39, S701-S704

6. Elbasset,A.; Abdi, F.; Lamcharfi,T.; Sayouri, S.; Aillerie, M . J International Review of Physics (IREPHY). 2013, 7 (3), 87-93.

7. Schunemann, P. G.; Temple, D. A.; Hathcock, R. S.; Tuller, H. L.; Jenssen, H. P.; Gabbe, D. R.; and Warde, C. JOSA B. 1988, 5 (8), 1685-1696.

8. Robert, N.; Barry, S.; Wechsler, A.; and West, L. Appl. Phys. Lett. 1995, 67, 1352

9. Kellati, M.; Thése de la faculté des sciences Dhar Mehraz, Fes, 2002.

10. Omari, M.H.; Thése de la faculté des sciences
Dhar Mehraz, Fes, 2000.

11. Hernandez-Cruz, D.; Sahouli, B.; Tork, A.; Knystautas, J.; and Lessard, R. A. Proceedings of SPIE 4296, Conf. Practical Holography XV and Holographic Materials VII. 2001, 244-248.

12. Tika, P. S .; Novesar, J .; Syukri; Zefri. A.; Asregi, A. Orient J Chem. 2014, 30(4), 6362.

13. Abo-Almaged, H. H.; Khattab. R. M.; and Sadek, H. E. H. Orient J Chem. 2016, 32(1), 243-251

14. Chaves, A.S.; Katiyar, R.S.; Porto, S.P.S. Phys. Rev.B. 1974, 10, 3522.

15. Sanjarjo, J.A.; Katiyar, R.S.; Porto, S.P.S. Phys. Rev. B. 1980, 22, 2396.

16. Loubbidi, L.; Naji, M.; Orayech, B;. Chagraoui, A.; Igartua, J. M.; Moussaoui, A.; Tairi, A.; and AitSidiAhmed, O. Orient J Chem. 2016, 32 (1), 47-57. 